\title{
Peran Public Relations Industri Musik dalam Membangun Reputasi (Analisis Terhadap DX Entertainment JKT48)
}

\author{
Shani Indira Natio, Sinta Paramita \\ shaaninatio@gmail.com Sintap@fikom.untar.ac.id \\ Fakultas Ilmu Komunikasi Universitas Tarumanagara
}

\begin{abstract}
Reputation is an important factor in maintaining a company's success. Having a good reputation means that the company will get many benefits, one of them is consuments loyalty. The existence of Public Relations is the spearhead to build the reputation, image, and public trust that will have a positive effect on the company's sustainability. The purpose of this research is to find out the role of DX Entertainment Public Relations in Building JKT48 Reputation. The theory used in this research is communication theory, public relations, and reputation. The research method uses qualitative with case studies. Research results show that DX Entertainment applied nine reputation management and public relations have role on JKT48's reputation.
\end{abstract}

Keywords: $d x$ entertainment, public relations, reputation.

\begin{abstract}
Abstrak
Reputasi merupakan faktor penting dalam mempertahankan kelangsungan hidup suatu perusahaan. Memiliki reputasi yang baik akan mendapatkan lebih banyak keuntungan salah satunya loyalitas konsumen. Adanya Public Relations menjadi ujung tombak untuk membangun reputasi, image, dan kepercayaan publik yang akan memberikan efek positif bagi kelanjutan perusahaan. Tujuan penelitian ini adalah mengetahui Peran Public Relations DX Entertainment Dalam Membangun Reputasi Grup Musik JKT48. Teori yang digunakan dalam penelitian ini adalah teori komunikasi, public relations dan reputasi. Hasil penelitian menunjukan bahwa DX Entertainment mengangkat sembilan manajemen reputasi dan public relations memiliki peran terhadap reputasi JKT48.
\end{abstract}

Kata Kunci: dx entertainment, public relations, reputasi.

\section{Pendahuluan}

Semakin ketatnya kondisi persaingan industri musik yang ada, menuntut para musisi untuk terus berinovasi. Hal ini merupakan sebuah kesempatan dan tantangan bagi para musisi di Indonesia baik penyanyi perorangan, band atau grup yang masih bertahan hingga sekarang. Masyarakat akan menjadi semakin selektif dan sensitif terhadap segala musik yang ada. Kondisi tersebut yang menekankan perusahaan untuk lebih teliti dan tanggap dalam proses produksi hingga distribusi.

Industri musik di Indonesia telah berkembang dengan pesat, dapat terlihat jelas dari banyaknya genre atau aliran musik yang tersedia hingga lahirnya para musisi berbakat. Namun, adanya krisis ekonomi dan pembajakan yang semakin marak terjadi, berimbas pada penjualan kepingan $C D$ yang terus menurun. Bedasarkan penjelasan Asosiasi Industri Rekaman Indonesia (ASIRI) pada marketeers.com tercatat hanya empat juta keping yang terjual pada tahun 2015 atau 
setara dengan 5\% dari keseluruhan jumlah keping yang tersebar di pasar Indonesia dan $95 \%$ penikmat musik tercatat sebagai illegal.

Survei Indonesian Streaming Music Consumption pada tahun 2017 menyatakan bahwa adanya layanan streaming musik tidak berbayar menyebabkan tingkat pembajakan semakin meningkat. Setiap tahun tercatat ada 2,82 miliar musik yang diunduh secara gratis dan menyebabkan industri musik mengalami kerugian sebesar 8,4 triliun (bisnis.tempo.co). Untuk menangani masalah tersebut pihak perusahaan, label musik atau management harus cerdas dalam mengatur strategi seperti live performance, event, konser, hingga iklan untuk mampu bertahan di era digital saat ini.

Reputasi adalah tujuan utama yang hendak dicapai dalam sebuah perusahaan (Lourensia \& Setyanto, 2018). Reputasi juga menjadi faktor penting untuk kelangsungan hidup perusahaan. Memiliki reputasi yang baik akan mendapatkan lebih banyak keuntungan salah satunya loyalitas konsumen. Morley berpendapat bahwa reputasi menjadi baik atau buruk, kuat atau lemah bergantung pada kualitas strategi dan komitmen perusahaan untuk mencapai tujuan yang telah ditetapkan serta adanya keterampilan atau energi dengan segala komponen program yang akan direalisasikan dan dikomunikasikan (Ardianto, 2011).

DX Entertainment sebagai anak perusahaan PT. Dentsu Aegis Network Indonesia sekaligus menjadi konten owner JKT48 sampai saat ini masih mampu bertahan dengan loyalitas konsumen dan reputasi perusahaan yang tinggi. Hal tersebut yang juga menjadi pengaruh utama bagi grup musik JKT48 sehingga mampu menjaga eksistensinya hingga sekarang.

JKT48 merupakan grup idola yang terbentuk pada tahun 2011 oleh produser sekaligus pencipta lagu dari Jepang, Akimoto Yasushi. Menurut Destria Aryani dalam artikelnya yang berjudul "Mengapa Banyak Orang Yang Tergila-gila Dengan JKT48?" mengungkapkan bahwa teknik branding dan pemasaran yang kreatif serta engagement yang tinggi dengan penggemar menjadikan JKT48 sebagai satu-satunya penyanyi di Indonesia kategori grup yang masih bertahan hingga saat ini.

DX Entertainment membentuk JKT48 untuk menjadi idola yang memiliki hubungan erat dengan para penggemar tanpa melebihi batas wajar serta melibatkan penggemar dalam beberapa keputusan atau tindakan yang dilakukan. Hal tersebut bertujuan untuk tetap menjaga ketertarikan, loyalitas, dan kepercayaan penggemar. Adanya inovasi yang terus dilakukan, membuat $D X$ Entertainment menjadi bukti salah satu perusahaan yang berhasil membangun reputasi yang baik serta mencuri perhatian publik.

Public Relations menjadi salah satu ujung tombak untuk membangun reputasi, image, dan kepercayaan publik yang akan memberikan efek positif bagi kelanjutan perusahaan. Ruang lingkup public relations tidak hanya dengan pihak internal, melainkan juga dengan pihak external yang berperan dalam kesuksesan perusahaan seperti pemerintah, komunitas, media, karyawan, hingga pemegang saham. Kegiatan yang berkaitan dengan public relations untuk membangun, menjaga, meningkatkan, memperbaiki prestise organisasi, mendeteksi dan menangani isu-isu yang beredar hingga mengatasi kesalahpahaman untuk mempertahankan reputasi perusahaan menjadi point penting yang perlu diperhatikan (Iriantara dan Surachman, 2014). Sebagaimana dengan fungsi public relations yaitu berfokus pada suatu masalah yang mempengaruhi citra dan reputasi perusahaan (Farleni dan Widayatmoko, 2014) 
Denny Griswold dalam buku Danandjaja (2011) mengungkapkan bahwa public relations sebagai suatu fungsi manajemen yang diharuskan untuk menilai sikap publik, menunjukan kebijaksanaan dan prosedur dari sorang individu atau kelompok atas dasar kepentingan publik, merencanakan serta menjalankan perencanaan kerja untuk mendapatkan pengertian yang dapat diterima baik oleh publik. Dengan demikian, public relations telah menjadi aset yang sangat berharga demi kelangsungan hidup sebuah perusahaan.

Penulis melakukan penelitian ini untuk mengetahui bagaimana peran public relations DX Entertainment dalam membangun reputasi grup musik JKT48 di tengah-tengah perkembangan industri musik di Indonesia dan juga maraknya budaya pembajakan musik di Indonesia.

\section{Metode Penelitian}

Penelitian yang dilakukan penulis menggunakan pendekatan kualitatif agar dapat meneliti secara mendalam mengenai bagaimana peran public relations $D X$ Entertainment dalam membangun reputasi grup musik JKT48 di tengah industri musik Indonesia saat ini. Penelitian kualitatif adalah metode yang digunakan dalam meneliti kondisi objek alamiah, dimana peneliti berperan sebagai kunci, analisis data bersifat induktif, dan hasil penelitian menekankan pada makna. Penelitian ini muncul karena adanya perubahan paradigma dalam melihat suatu fenomena atau realitas sosial (Sugiyono, 2015)

Penelitian yang dilakukan menggunakan metode studi kasus dimana peneliti mengangkat suatu kasus yang dikaji secara mendalam sehingga dapat menemukan realitas di balik masalah yang diteliti. Studi kasus ialah suatu metode dalam penyelidikan sebuah fenomena di dalam konteks kehidupan nyata. Studi kasus merupakan penelitian dalam individu, kelompok, atau organisasi mengenai peristiwa untuk mendapatkan gambaran secara mendalam tentang suatu kasus yang sedang diteliti (Sujarweni, 2014).

Objek dalam penelitian ini adalah reputasi DX Entertainment sebagai manajemen JKT48 yang berlokasi di Jl. Simprug Golf III No. 112, RT.3/RW.8, Kebayoran Lama, Jakarta Selatan 12220. Sedangkan subjek dari penelitian ini adalah : Fritz Fernandez, Putriasihta Baeha, Feni Fitriyanti, Rezza Habibie. Metode pengumpulan data pada penelitian ini dibagi menjadi 2 yaitu pengumpulan data primer yang berupa wawancara dan observasi partisipan, sedangkan untuk data sekunder didapat dengan studi pustaka, penelusuran data online, dan dokumentasi.

\section{Hasil Temuan dan Diskusi}

Tak bisa dipungkiri bahwa kini industri musik di Indonesia telah berkembang dengan pesat. Tetapi karena adanya revolusi media, banyak para penyanyi solo maupun grup yang seketika kandas ditengah jalan. Berbeda dengan grup musik JKT48 yang hingga kini masih mampu menjaga eksistensi di dunia entertainment dan berhasil menjadi satu-satunya penyanyi di Indonesia kategori grup yang masih bertahan hingga saat ini. Hal ini terjadi karena adanya reputasi yang baik dan juga komunikasi serta hubungan yang erat dengan berbagai pihak yang berkepentingan baik internal maupun external. 
Membangun reputasi tidak dapat dilakukan dengan waktu yang singkat. Reputasi bagaikan sebuah aset yang tidak tampak bagi perusahaan. Ketika dapat dikelola dengan baik, reputasi dapat meningkatkan kemampuan perusahaan untuk melakukan promosi dalam penjualan produk atau jasa, menarik investor, dan mempekerjakan pekerja yang berbakat. Untuk membangun reputasi terdapat beberapa pendekatan yang diungkapkan secara teori, yaitu: (Gassing dan Suryanto, 2016

\section{Analisis Reputasi}

Dalam analisis ini, berkaitan dengan mencari tahu dan mengidentifikasi kekuatan, kelemahan, tantangan, serta ancaman perusahaan.Pada bagian ini bapak Fritz Fernandez mengatakan bahwa kekuatan JKT48 adalah adanya fans yang loyal. Dengan adanya sarana yang disediakan DX Entertainment untuk menyebarluaskan informasi melalui media sosial juga menjadi kekuatan tersendiri yang kemudian dicari oleh berbagai macam brand.

JKT48 memiliki peraturan ketat yang disebut golden rules, namun peraturan tersebut rupanya juga menjadi kelemahan bagi grup. Sebab, terdapat beberapa peraturan yang sebenarnya tidak sesuai dengan budaya di Indonesia, tetapi tidak dapat diubah karena semua peraturan yang tertera adalah konsep yang harus diikuti oleh seluruh keluarga 48 baik yang berada di Jepang maupun yang berada di luar Jepang.

Walaupun terkadang para penggemar merasa memiliki kuasa, tak bisa dipungkiri bahwa sebenarnya peran penggemar sangat berpengaruh pada kelangsungan hidup JKT48. Sejak pertama kali debut, tidak ada yang berpikir bahwa grup ini mampu bertahan hingga sekarang. Melakukan regenerasi dan memiliki penggemar yang loyal tidaklah cukup bagi JKT48. Meskipun telah bertahan hingga 8 tahun, tantangan terbesar bagi JKT48 adalah bagaimana cara supaya dapat bertahan di industri musik Indonesia.

Grup ini juga memiliki beberapa ancaman yang dirasa perlu diperhatikan supaya tidak berkembang menjadi masalah. Ancaman tersebut dibagi menjadi dua yaitu internal dan external. Ancaman internal berasal dari anggota JKT48 yang berperilaku buruk sehingga merugikan JKT48, sedangkan ancaman eksternal berasal dari perkembangan platform musik.

\section{Perencanaan Strategis}

Perencanaan Strategis merupakan sebuah perencanaan berupa program kerja strategis untuk diterapkan pada publik atau target pasar. Program yang dijalankan harus sesuai dengan visi dan misi perusahaan.Salah satu program yang hanya dimiliki oleh JKT48 adalah theater Karena JKT48 adalah idol yang tumbuh dan berkembang bersama penggemar, sehingga melalui pertunjukan theater yang diadakan hampir setiap hari para penggemar dapat menyaksikan perkembangan anggota secara langsung.

Kemudian program lain yang hanya dimiliki JKT48 adalah handshake event. Bagi penggemar JKT48 yang berbasis di luar Jakarta. Terdapat program khusus yaitu "JKT48 Circus".JKT48 juga memiliki acara pemilihan anggota untuk membawakan single terbaru JKT48 melalui voting. Posisi yang didapatkan akan sesuai dengan jumlah voting yang didapatkan Kemudian, JKT48 selalu melakukan konser setiap tahunnya. Baik itu konser anniversary atau konser untuk kelulusan member yang dikenal dengan kata graduation.Stakeholders Relations 
Menjalin hubungan berkepanjangan dengan stakeholders menjadi kemudahan bagi perusahaan untuk menyampaikan informasi dan mengaplikasikan program yang berhubungan dengan membangun reputasi. JKT48 memiliki stakeholders yang cukup banyak. Dalam upaya menjalin hubungan, DX Entertainment sebagai perusahaan di bawah Dentsu Inc, melakukan report line menjadi sebuah kewajiban. Karena JKT48 juga merupakan grup dari keluarga 48, pihak $D X$ Entertainment juga wajib memberi laporan pada $A K S$ selaku konten owner dari keseluruhan 48 grup.

Karena JKT48 adalah grup yang dekat dengan penggemar, DX Entertainment menyatakan bahwa penggemar merupakan stakeholders utama. Sebab 70\% pendapatan didapatkan dari penggemar melalui hasil penjualan $C D$, merchandise, pertunjukan theater, handshake event, konser, dan juga voting. Selain itu keaktifan di media sosial juga menjadi cara yang paling efektif untuk menjalin hubungan dengan para penggemar.

Stakeholders tidak hanya dari pihak external, menjalin hubungan dengan pihak internal juga perlu diperhatikan. Selain penggemar, seluruh anggota JKT48 juga menjadi stakeholders utama dalam grup ini. Walaupun DX Entertainment adalah perusahaan dengan struktur organisasi yang tersusun jelas, ternyata mengaplikasikan metode komunikasi top down dianggap kurang efektif. Sehingga, $D X$ Entertainment melakukan komunikasi yang lebih mendalam kepada kapten atau center di setiap tim.

\section{Memantau Media}

Melakukan pemantauan terhadap komentar hingga laporan terkait perusahaan di berbagai media saat ini menjadi sebuah keharusan oleh perusahaan. Hal tersebut dilakukan guna melihat ketertarikan konsumen dan tingkat kepuasan konsumen untuk dijadikan sebagai bahan evaluasi perusahaan. JKT48 terbilang cukup aktif di media sosial terutama twitter dan instagram. Dalam pemantauannya, pihak $D X$ Entertainment memiliki staf yang dikhususkan untuk memperhatikan perkembangan di media sosial baik itu isu, komentar, atau aktivitas yang berkaitan dengan grup.

\section{Pelatihan Media}

Pada bagian ini, perusahaan memberikan pelatihan kepada praktisi public relations terkait media massa. Dari informasi yang didapatkan dari Ibu Putri, saat ini DX Entertainment memiliki lebih dari 50 staff yang terbagi menjadi beberapa divisi.Staff yang berkepentingan diberikan training dan briefing terlebih dahulu supaya memahami bagaimana konsep grup JKT48, peraturan yang ada, dan bagaimana cara bersikap untuk memperkenalkan para anggota pada pihak external. Seluruh informasi akan dijelaskan secara detail pada masa orientasi tersebut.

Tidak hanya staff saja, tetapi seluruh anggota JKT48 juga diberikan pelatihan mengenai media sosial. Terutama anggota baru, akan diberi pemahaman bagaimana dos and don'ts dalam berinteraksi dan sebagaimana media sosial tersebut digunakan sebagai seorang idol. Walaupun terdapat beberapa peraturan dalam bermedia sosial tetapi DX Entertainment tidak membatasi para anggota untuk tetap menjadi diri sendiri.

\section{Materi Komunikasi}

Materi komunikasi merupakan rancangan naskah untuk media terkait kebijakan, produk, program, dan promosi yang berkaitan dengan reputasi perusahaan. DX Entertainment selalu memberikan materi kepada media berupa pre- 
event release dan post event release. Tetapi, materi yang diberikan kepada media sebelum event berlangsung, hanya sebatas informasi mendasar, hal tersebut dilakukan karena konten dan isi mengenai event masih bersifat rahasia, sehingga $D X$ Entertainment tidak bisa memberi bocoran kepada media secara detail terkait event yang akan dilaksanakan.

\section{Media Relations}

Demi mempertahankan reputasi, perusahaan harus senantiasa menjalin hubungan harmonis dengan berbagai media guna memudahkan perusahaan dalam segala kepentingan. Begitu pula dengan DX Entertainment yang cukup dekat dengan berbagai media sehingga memudahkan JKT48 jika ingin menyebarluaskan suatu informasi. Untuk mempermudah, terdapat divisi tersendiri yang khusus mengelola koneksi terutama untuk media TV, radio, koran, dan media online.

\section{Government Relations}

Government Relations diartikan sebagai adanya hubungan yang baik dengan pemerintah yang memiliki wewenang terkait regulasi dan pendukung kebijakan perusahaan. Pihak Dentsu Aegis Network cukup banyak diberi dukungan dari pemerintah. Sama dengan $D X$ Entertainment yang juga memiliki hubungan dengan pemerintah terutama dalam hal membayar pajak.

\section{Manajemen Isu}

Dunia entertainment memang sering tertimpa isu negatif dari sumber yang berbeda dan dengan tingkat penyebaran yang berbeda pula. JKT48 seringkali mendapat isu-isu yang kurang baik seperti gossip hingga tersebarnya dokumentasi atau video skandal para anggota yang melanggar aturan. DX Entertainment selalu melakukan cross check terlebih dahulu sebelum mengambil sebuah keputusan. Tetapi sebisa mungkin perusahaan meminimalisir adanya permasalahan terutama yang menyangkut para anggota sebab JKT48 sangat bergantung pada kepercayaan penggemar. Ketika terdapat anggota yang tidak mematuhi peraturan, maka kepercayaan tersebut akan hancur dan mempengaruhi reputasi perusahaan. Oleh sebab itu, jika hal ini terjadi pihak DX Entertainment tidak segan untuk menghukum kepada anggota yang bersangkutan.

Tabel 1. Ringkasan Hasil Penelitian

\begin{tabular}{|c|c|c|}
\hline \multirow{2}{*}{ No. } & \multirow{2}{*}{ Manajemen Reputasi } & Hasil Penelitian \\
\hline & & Tidak \\
\hline 1 & Analisis Reputasi & \\
\hline 2 & Perencanaan Strategis & \\
\hline 3 & Stakeholders Relations & \\
\hline 4 & Memantau Media & \\
\hline 5 & Pelatihan Media & \\
\hline 6 & Materi Komunikasi & \\
\hline 7 & Media Relations & \\
\hline 8 & Government Relations & \\
\hline 9 & Manajemen Isu & \\
\hline
\end{tabular}


Shani Indira Natio, Sinta Paramita: Peran Public Relations Industri Musik Dalam Membangun Reputasi (Analisis Terhadap DX Entertainment JKT48)

\section{Simpulan}

Berdasarkan temuan dan analisis di atas, maka dapat diambil sebuah kesimpulan bahwa $D X$ Entertainment menerapkan ke-sembilan manajemen reputasi. Hasil dari penelitian ini menunjukkan bahwa komunikasi terutama public relations memiliki peran terhadap reputasi grup musik JKT48.

DX Entertainment sebagai konten owner JKT48 memberikan beberapa fasilitas salah satunya adalah theater dan media sosial sehingga para penggemar juga dapat menyaksikan perkembangan anggota secara langsung setiap harinya. Pertunjukan Theater, Handshake Event, JKT48 Circus, dan Pemilihan Member adalah beberapa aktivitas yang rutin diadakan. Konsistensi tersebut yang juga menjadi salah satu alasan mengapa grup ini masih mampu bertahan di industri musik Indonesia.

DX Entertainment memiliki hubungan yang baik antara staff dan anggotanya. Tidak hanya dengan pihak internal saja, tetapi juga berkomunikasi secara persuasif dan informatif kepada pihak external yang diharapkan mampu mendapat kepercayaan dan menciptakan reputasi yang baik atas perusahaan dimata publik.

Dalam menangani permasalahan yang beredar, DX Entertainment tidak segan untuk memberikan sanksi atau hukuman jika terbukti bersalah. Semua ini dilakukan supaya para anggota disiplin terhadap peraturan yang ada dan diharapkan bisa menimbulkan kesadaran akan tanggung jawabnya sebagai seorang public figure.

\section{Ucapan Terima Kasih}

Penulis mengucapkan terima kasih yang sebesar-besarnya kepada seluruh pihak yang telah membantu penulis selama proses penelitian ini berlangsung sampai dengan terbitnya publikasi atas hasil penelitian ini.

\section{Daftar Pustaka}

Ardianto, Elvinaro. (2011). Metodologi Penelitian Untuk Public Relations Kuantitatif Dan Kualitatif. Bandung: Simbiosa Rekatama Media.

Aryani, Destria. (2018, 27 April). Mengapa Banyak Orang Yang Tergila-gila Dengan JKT48?.Agustus 18, 2019.

https://id.quora.com/Mengapa-banyak-orang-yang-tergila-gila-dengan-JKT48

Danandjaja.(2011). Peranan Humas dalam Perusahaan. Yogyakarta: Graha Ilmu.

Farleni dan Widayatmoko. (2014). Peran Public Relations Kepolisian Republik Indonesia Melalui Media Relations Dalam Membangun Citra Yang Lebih Baik. Jurnal Komunikasi, Universitas Tarumanagara, 6, 12-18.

Gassing, Syarifuddin S. dan Suryanto.(2016). Public Relations. Yogyakarta: Andi Offset.

Iriantara, Yosal dan A. Yani Surachman.(2014). Public Relations Writing Pendekatan Teoritis dan Praktis. Bandung: Simbiosa Rekatama Media.

Lourensia, F., \& Setyanto, Y. (2018). Peran Public Relations dalam Memulihkan Reputasi ( Studi Kasus Manajemen Krisis PT Kereta Commuter Indonesia Pasca Perubahan Sistem E-Ticketing) | Lourensia | Prologia. https://doi.org/10.24912/pr.v2i2.3595

Sugiyono.(2015). Metode Penelitian Pendidikan (Pendekatan Kuantitatif, Kualitatif dan $R \& D)$. Bandung: CV. Alfabeta. 
Sujarweni, V. Wiratna.(2014). Metode Penelitian: Lengkap, Praktis, dan Mudah Dipahami. Yogyakarta: Pustaka Baru Press.

Fernandez, Fritz. (2019, Oktober 31).Wawancara pribadi.

Baeha, Putri Ashita. (2019, Oktober 21).Wawancara pribadi.

Fitriyanti, Feni. (2019, November 21). Wawancara pribadi.

Habibie, Muhammad Rezza. (2019, November 21). Wawancara pribadi. 